\title{
Gold, Gods and Women
}

\author{
Marta Lindeberg
}

\begin{abstract}
Women in Iron Age Scandinavia were not passive homemakers. Instead they had considerable interest in and occasional influence over events outside the domestic sphere. Through a study of the gold bracteates - their function, runic inscriptions and iconography - the role of women will be investigated. Gold bracteates were not artefacts with exclusively male associations, but rather, they demonstrate the influence of women in political matters.
\end{abstract}

Marta Lindeberg, Department of Archaeology, Stockholm University, SE-106 91 Stockholm, Sweden.

The stereotypical image of Iron Age woman as a passive homemaker with little or no interest or influence outside the domestic sphere may need to be reconsidered, since the influence of women in the political sphere has not been sufficiently acknowledged. By using the gold bracteates as a starting point, this study will attempt to give a more balanced analysis of the female gender roles during the Iron Age. The function, iconography and runic inscriptions of the bracteates have generally been considered in terms of masculine contexts, in spite of the fact that bracteates are often found in feminine contexts.

\section{GOLD BRACTEATES}

Gold bracteates were used during the Migration Period in southern Scandinavia, but are also found in England and central Europe. Bracteates are found both in graves and in hoards, but there are significant differences in their distributions. Hoards are found in Denmark, southern Sweden, southern Norway and on the southern Baltic coast. Ouside this central territory, gold bracteates only occur in graves, except in southern and western Norway where they are found in both graves and hoards (Andrén 1991:246). According to Karl Hauck, the hoards containing bracteates can be attributed to both men and women, and bracteates in graves largely to women (Hauck et al. 1985:11f). There are a number of exceptions which occur also in southern and western Norway, where bracteates have been recorded in male graves (Andrén 1991:246).

Bracteates were worn around the neck as pendants and may have been intended as protective amulets. They were, however, primarily ornaments of prestige which indicated that the wearer belonged to the highest social-economic class (Axboe 1990:27).

Bracteates have been analyzed thoroughly by Öberg (1942), Mackeprang (1952), Malmer (1963) and Hauck et al. (1985) among others.

\section{THE POLITICAL ENVIRONMENT}

Gold bracteates appeared at a time when the social system founded on kinship was no longer in sole control. During the Migration Period a number of small chiefdoms developed, which struggled against each other for dominance. Increasingly, these chiefdoms evidently had to build alliances over larger geographical areas than had previously been necessary. Tove Hjørungdal (1991:112ff) has 
analyzed the archaeological material from Vestlandet in Norway, and she regards the early Iron Age as a period characterized by ideological conflicts between the older, kinship-based society, which was largely maintained by women, and the newer maledominated political system of chiefdoms, which depended on greater contacts and alliances between groups separated by vast geographical distances. This new system engendered a new aesthetic of the masculine warrior, which is subsequently reflected in the weapon graves. The retinue was of greater importance in this new social system (Hedeager 1992:184ff; Axboe 1996:196). The Migration Period is regarded as a time characterized by widespread violence and upheaval. Charlotte Fabech is of the opinion that the people of this period lived in societies which were affected by aggression and war (Fabech 1991:283) and that this is reflected, for example, in the war-booty sacrifices (for a different opinion on the crisis of the Migration Period, see Näsman 1988).

The standard view of the Migration Period might be considered over-simplified and onedimensional. If this is the case, certain modifications of this view may be in order. For example, war and aggression have been over-emphasized and less attention has been paid to the more mundane aspects of life in the period. As a result, gold bracteates have been given an all too militaristic interpretation, in which male associations are taken for granted.

In the evolving chiefdoms of the Scandinavian region a system of reciprocal giftgiving developed as a means of consolidating and ensuring mutual trust and goodwill between the different groups involved in political alliances, as they were not kinsmen. The gift was a potent tool for forging new alliances or reaffirming old ones (Vestergaard 1991:98). Aron J. Gurevich describes the relationship between giver and receiver as characterized by "magic dependence" (Gurevich 1985:223). In this climate, in which bonds of kinship were supplemented by political alliances, gold bracteates held special significance in the exchange of gifts. As both jewellery and gifts, gold bracteates demonstrated prestige and the highest political status.

\section{THE ROLE OF WOMEN IN IRON AGE SOCIETY}

The division of labour in Iron Age Scandinavia is generally regarded in terms of a rigid separation between the public sphere, which was controlled by the men, and the domestic sphere to which women were confined. Seemingly, the dividing line between the public and domestic spheres was drawn at the threshold. Any work or chores within the home was the sole responsibility of the women. Similarly any work outside was performed by the men (Holtsmark 1964:565). This division of labour, which is regarded as having been a social norm, can be traced back to the writings of Aristotle. This model prevails, and even today it is used uncritically (Arwill-Nordbladh 1994:36ff). This conventional view of the division of labour in prehistoric societies does not give a comprehensive picture, and therefore the conclusions drawn from these notions regarding male and female activity are fallacious. Indeed it might be said that differences between the gender roles of men and women have been over-emphasized, and consequently the potential for both men and women to transgress the imagined boundaries of their respective spheres, has been overlooked. By confining male and female gender roles and behaviour-impermeable spheres, a rigid framework is established which cannot easily accomodate evidence which is suggestive of such transgressions. Indeed, such evidence is often omitted or regarded as anomalous or marginalised for precisely this reason. In other words, it would be better to avoid such inflexible stereotypes in favour of a looser model in which the traditional roles of men and women might more easily overlap.

The state of opposition that Hjørungdal (1991:112ff) discerns between the old kinshipbased ideology maintained by women and the 
male warrior aesthetic, might not stand in sharp contrast to each other. The differences that appear in the archaeological material found in graves may evoke the different roles played by men and women in this period, rather than being evidence of a conflict of interests between the two groups. The two different ideologies may be regarded as complementary rather than in opposition to each other, and both systems were necessary to accomodate changes in society.

Many different conclusions have been drawn from the analyses of Old NorseIcelandic literature, in which women are often decribed as strong and willful. Therefore the opinions regarding the postion of the Iron Age women vary accordingly. The literature is considered to reflect that strong and independent women were apparently typical (Guttormsson 1992:188; Mundal 1992). Alternatively, it has been argued that such literature should be regarded in terms of propaganda written by men of the church to emphasize their progress towards civilization since heathen times and to denounce independent women (Jochens 1986). Naturally these analyses are not wholly objective but are coloured by personal views, and consequently the conclusions regarding the prehistoric woman become biased to a certain extent. One example of this is the image of Iron Age woman as homemaker, responsible for the family budget, which is manifest in descriptions of the Viking Age (Arwill-Nordbladh 1991). There is widespread agreement that women of the period rarely, if ever, ventured outside their allotted sphere of influence. However, by comparing legal documents with rune stones and registers of landed property, Birgit Sawyer has come to the conclusion that the position of women in the late Iron Age was not as restricted as it appears in legal documents of the time. Sawyer is of the opinion that "both prehistoric and medieval women, in practice, were able - and expected - to act independently, although different customs, ideals and laws formally restricted their liberty of action" (Sawyer
1994:6, my translation).

Another example of the permeability between the roles of men and women is the Viking Age rune stone from Jättendal, Hälsingland, which was carved by a woman (Klintberg 1996). The complementary roles of men and women in the division of labour were conditioned culturally and were to a greater extent fixed, which naturally limited personal choice. However, a certain merging of the gender roles was necessary in some situations. Perhaps gold bracteates reflect a situation in which the role of women was pivotal to the public sphere.

In Norse-Icelandic literature it was the woman who could, without putting her honour at stake, cross the division between the gender roles. The same kind of overstepping of boundaries by a man was not socially acceptable. A man in this situation would lose social status, whereas a woman could occasionally behave in a way which was traditionally regarded as masculine. These women are portrayed favourably in the literature, and it is emphasized, by stressing their femininity and female characteristics, that they were not considered manly. Strong women were appreciated, and the strength of men and women was regarded equally (Meulengracht Sørensen 1993:206).

It is essential that the general view of Iron Age women is discussed in depth, as the image that is often put forward is too simplistic and overlooks important subtleties.

\section{WOMEN AND ALLIANCES}

As mentioned previously, the gold bracteates have been interpreted as a medium that facilitated political arrangements. A large part of the bracteates have been found in contexts that are associated with women and, according to Birgit Arrhenius this may reflect the fact that bracteates were used as morning gifts, as gold bracteates have occasionally been found in Frankish graves with otherwise non-Scandinavian artefacts (Arrhenius 1992). However, this interpretation is too narrow, since women 
enabled alliances not only when they got married, but also in many other situations. Anders Andrén (1991) is of the opinion that the bracteates demonstrate that women were seen as makers of political alliances, and furthermore that the gold bracteates have functioned as ethnic markers for groups of people outside the Scandinavian region who claimed a southern Scandinavian heritage. Gold bracteates are, for instance, found in female graves in Kent, in southern England, where the leading families traced their descent from Jutland, Denmark. The function of the gold bracteates has thus changed over time and over geographical areas (ibid:254).

One of the most important ways to create or preserve alliances in Migration Period society was through marriage between people of different families. A marriage involved longterm legal as well as moral obligations and was therefore considered especially reliable. In Anglo-Saxon poetry the wife is given the name "peace-weaver" as the possibility of peace between the two families was significantly improved, and this also is believed to apply to the Germanic peoples (Arrhenius 1992:20; Enright 1990:66).

Marriage probably had the form of a contract between the families of the bride and groom, who were expected to be of equal social standing and comparable wealth (Sawyer 1992:38). There is much to indicate that neither the man nor the woman had any influence over the choice of the person they married (Meulengracht Sørensen 1993:177). Nevertheless women as well as men had a strategic interest in marrying as well as possible since that gave honour, which was of great social importance. This increase in honour strengthened the social position of the family (ibid:231). The woman was seen as the guardian of honour and was in some ways responsible for making sure the honour was not lost (ibid:246). To be able to do this, she had to act.

Since the gender role of the woman restricted her to the domestic realm, she had no direct influence in the public areas of society. However, this did not imply that she was passive; rather, she had to act indirectly through the men to have an effect on activities that took place outside the household. One important factor that rendered this possible was, as Sverre Bagge points out, that the woman had room to operate as a consequence of belonging not only to her own family but also to that of her husband (Bagge 1990:21). In addition to this, her children were completely integrated into her husband's family. Furthermore Bagge believes that the woman could act indirectly through her sons, which would have been particularly effective in conflicts with her husband. The relationship between the sons and their father was probably characterized by competition; the sons were in an inferior position until the death of their father, and therefore the position of the woman was strengthened by the support of her sons (ibid:21). The spatial restrictions of the woman were moreover compensated by verbal action. Agneta Breisch sums up the situation: "The men had the swords, the women had their tongues" (Breisch 1994:86, my translation). The Hetzerin motif which is frequent in the Norse literature, whereby women goad their reluctant husbands or male relatives into taking revenge, is a reflection of this strategy by women to participate verbally (ibid:86; for a different opinion see Jochens 1986:49f).

Consequently the woman as well as the man had an interest in strengthening the social position of the family, although their ways of achieving this were different as they were restrained by their culturally-defined gender roles. The woman should therefore not merely be seen as a passive object of exchange in the marital barter.

\section{RUNIC INSCRIPTIONS ON BRACTEATES}

The role of the woman as a facilitator of alliances was important not only in marriage affairs but in other situations as well, and this 
is reflected in the runic inscriptions on the gold bracteates. Andrén (1991) has analyzed the words lapu, alu and laukaR that occur in 22 bracteate inscriptions, and he has been able to show that the Germanic bracteates have copied form and function from the Roman imperial coins.

The first two words, lapu and alu, meaning invitation and mead, point clearly to the kind of situations in which bracteates were worn: at feasts where useful contacts were made or maintained and oaths of allegiance were taken. The inscriptions reflect the role of women in these circumstances. The woman hosted these festive gatherings, where high status was attained through generosity. Hospitality, which was the responsibility of the woman, was of great importance in Iron Age society. The woman could, through invitations, establish relations with other households and as a result of this could take on duties that were usually the responsibility of the man (Bagge 1990:21). To arrange feasts and to give gifts were of the utmost significance when attempting to improve or strengthen the social position in the Scandinavian Iron Age society (Gurevich 1985:239).

There seems to have been a special connection between mead and women, not only because it was the women who brewed it but also because they played an important role at the occasions on which it was consumed. According to Norse-Icelandic literature, it was women who had the mead already prepared for the occasions when the men drank toasts to one another to confirm oaths and agreements (Andrén 1991:253). The responsibility of the women in this situation is further indicated by the pendants found depicting women holding drinking-horns. The same theme occurs on a number of Gotlandic picture stones where a man, interpreted as Odin, is greeted by what is presumed to be a valkyrie holding a horn of mead (Andrén 1993:41). The task of the valkyries to offer mead to Odin reflects the responsibility of the ordinary women to serve food and drink to their men (Jesch 1991:127).
Furthermore it is described in the NorseIcelandic literature that it was the responsibility of priestesses (gydjorna) to bless the mead before the ritual sacrifices (Adolfsson \& Lundström 1993:11). All these examples point toward the special connection between women and mead, and this connection is also clearly demonstrated on the bracteates.

The third word, laukaR, meaning onion, also occurs in Old Norse literature. Onions principally occur in works dealing with fertility and are primarily connected with women. One well-known example is from Flateyjarbók, in which there is a description of a fertility rite where a horse's penis and some onions were wrapped together in linen. The woman of the house is in charge of the ceremony (Steinsland \& Vogt 1981:87). The inscription laukaR also occurs on a number of bone knives from western Norway. These knives have only been found in female graves and the complete inscription reads linalaukaR, meaning "linen and onions" (Hjørungdal 1991:108; Magnus 1992:140). The alliterative linalaukaR is presumed to be part of an old chant (galder) that was used in connection with fertility rites (Steinsland \& Vogt 1981:93). Another reason to associate the symbolism of the onion with women is that powers attributed to the onion are often represented within traditional Old Norse women's names. For example, names ending in -gerd and -borgh are associated with fertility and protection (Otterbjörk 1968:208). The biggest sources in terms of names are the runic inscriptions and the Old Norse literature, which are largely of later origin than the bracteates, but there is a distinct continuity in the use of personal names from the Migration Period up to the Viking Age (Hald 1968:217).

Consequently the runic inscriptions in this group can be attributed equally to male and female settings, although the personal names on the bracteates, which have so far been identified, are male names. The bracteates reflect the responsibilities of women in political situations, and even though these situations 
have been dominated by men the role of women is described on the bracteates.

\section{THE ICONOGRAPHY}

The iconography of the bracteates is difficult to interpret. This is due to the fact that an entire series of events is depicted in one motif (Hauck et al. 1985; Arrhenius 1987:111). The same holds true for the Gotlandic picture stones in which one figure might represent an entire myth. Both on the picture stones and on the bracteates a man, who has been interpreted as Odin, occurrs frequently (Andrén 1993:41). This type of picture stone belongs to a later period, the Viking Age (ibid:36), but can serve as an example of an art form that in many ways resembles that of the bracteates.

Few bracteates are identical. Most have minor differences even though they were sometimes manufactured using the same die. It seems as if the variations in symbolism were deliberate and that the different combinations of symbols had different meanings. The differences between the bracteates were, therefore, intentional (Arrhenius 1987:110). Perhaps the bracteates were intended for a particular person already at the stage of manufacturing, and the symbolism may therefore have been adapted to suit that specific person. This might explain why the bracteates were never mass-produced, even though it would have been technically possible. Only one or two identically imprinted bracteates have been recovered (Axboe 1992:50).

\section{ODIN AS WAR-GOD}

The iconography of the bracteates fits well with the idea of the Migration Period as a time of intense competition, fragile alliances and war. Scenes from Germanic mythology are depicted on the bracteates, and the god that appears most frequently is Odin (Axboe 1991:193). The inscription houraR on a bracteate from Funen, in Denmark, supports this theory. HouraR literally means "the High One", and it is the same name that is used for Odin in Hávamál, that is, "the Speech of the
High One". The reason why Odin occurs most frequently on the bracteates is believed to be that people in such hostile times gave prominence to the god of war over other, less belligerent, gods (Axboe 1990:27, 1991:196). The depicted symbolism and mythology is regarded as militaristic and by association male. As a consequence there appears to be a conflict between the male iconography and the prevalence of female find contexts (Lamm 1994:53).

Odin is believed to have appealed primarily to men who prayed for victory in war (Sawyer 1992:79). Through this focus on Odin in his capacity of war-god his other characteristics are overlooked, though they are equally, if not more important in this context. The gods of Germanic mythology are complex and have several, often paradoxical, features. Odin is the god of war but he is also the god of knowledge and magic, and it is in this sense that he should be regarded on the bracteates.

The reason Odin is regarded somewhat one-dimensionally as a war-god could be that research has concentrated on the appearent conflict between two different religious systems: the asir cult and the vanir cult. The vanir cult is believed to originate from the Nerthus cult in the Bronze Age in which women had a strong position. Peace and fertility were central, and the importance of kinship was also emphasized. The vanir cult is believed to have been in opposition to the maledominated, war-oriented æsir cult, where loyalty and camaraderie were given priority over kinship (Sawyer 1992:79; Hjørungdal 1991:104). By viewing the two cult systems as conflicting, the obvious differences between the systems come into focus. The female, fertility-based, vanir cult has been contrasted with the male, war-oriented, æsir cult in a way that might not be accurate. As a result the image of Odin has become biased and his warlike characteristics have been overemphasized, and consequently his other features have been left out.

Instead of regarding the systems as 
opposites they should be seen as two complementary, intertwined systems. In her analysis of Vestlandet in Norway, Hjørungdal does not find any indications of a conflict between the different cult systems during the early Iron Age. A number of graves can be attributed to both systems (Hjørungdal 1991:109).

\section{ODIN AS GOD OF KNOWLEDGE} AND MAGIC

Odin is not depicted on the bracteates as the war-god but rather in his capacity as the god of knowledge and magic. A good example of this is a group of C-bracteates that have been interpreted by Hauck as Odin breathing life into Balder's injured horse (fig. 1). $\mathrm{He}$ is helped by some birds that can be seen on some of the bracteates (Axboe 1992:49). Odin is able to heal the injured horse as he has supernatural abilities and knowledge of sorcery.

In the Ynglinga saga there is a passage describing how Odin learns the practice of seidr, which with the exception of Odin was an exclusively female activity. Seidr was sorcery used, for example, to gain knowledge about the future or to destroy an enemy (Strömbäck 1968:76). The practice of seidr was linked to the concept of ergi, which meant that a male practitioner would become more feminine and run the risk of losing his masculinity (Brendalsmo \& Røthe 1992:93). The only male that could be associated with ergi was Odin, since the loss of honour would be too great for an ordinary man who would lose social status. The concept of ergi is very close in meaning to the word argr, which denotes the passive man in a homosexual encounter. It was not primarily the homosexuality in itself that was frowned upon but rather implied passivity, cowardice and weakness, which were regarded as exclusively female features (ibid:93). To be accused of arg $r$ was the most devastating thing that could happen to a man and as a consequence many people could be killed in retaliation (Steinsland 1990:61). In Lokasenna there is a passage describing how Loke derides Odin and accuses him of having practiced seidr in a state of ecstacy like a sorceress. Even Odin's manhood is questioned by Loke, and Odin is said to be of args adal (Strömbäck 1935:57). The danger of being associated with argr is also indicated by the curse on the rune stones in Björketorp and Stentoften, in Sweden, where the word occurs (Jacobsen 1935:57).

When Odin practiced seidr or performed sorcery he was in a state of ergi and therefore his nature had as many female as male characteristics. Consequently Odin was able to move between male and female just as he was able to shape-shift and change into animals, which is also depicted on the bracteates. It is Odin's ability to transform and to cross borders that is important in the study of the iconography of the bracteates. The iconography of the bracteates can not be regarded as purely male, as Odin is often depicted in the mythological scenes as androgynous.

\section{BALDER AND TYR}

Balder and Tyr are two other gods that are

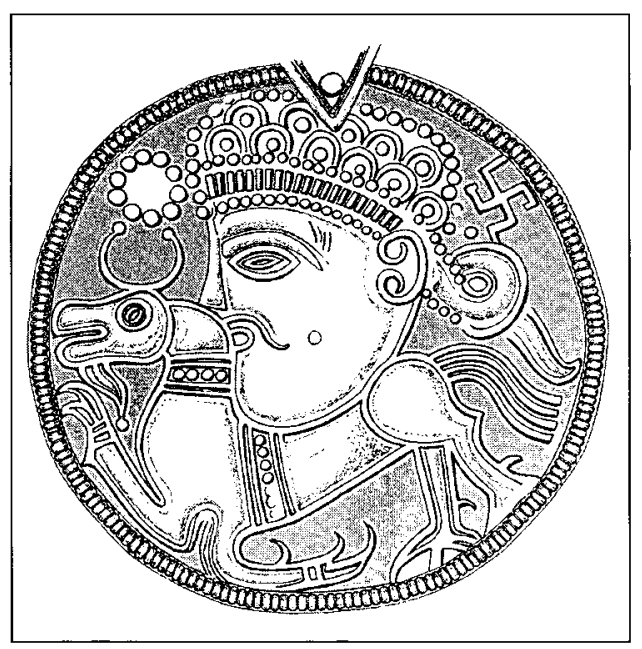

Fig. 1. Bracteate from Dödevi, Öland (Hauck 1992). 
frequently depicted on bracteates and have also been interpreted as having a male association, as they personify archetypal male characteristics.

The bracteates that depict the death of Balder are difficult to classify as male or female. In Germanic mythology Balder was the son of Odin, and he was wise, handsome and popular among the other gods. He dies after being shot with a twig of mistletoe, the only thing in the entire world that can injure him. Balder is often portrayed as quite passive in the myths; he may, however, have had more warlike characteristics in earlier versions. His name occurs in kennings to mean warrior (Bæksted 1990:157). On the bracteates Balder is depicted with the mistletoe hanging out of his chest and he is flanked by a figure on each side (fig. 2). One figure is supposedly Odin and the other is Loke, the instigator of the murder (Axboe 1991:193f).

One of the mythological scenes depicting Tyr is the one in which the wolf Fenrir bites his hand off (fig. 3). The wolf became too strong for the æsir to control, and in order to chain him Tyr put his hand into the mouth of the wolf

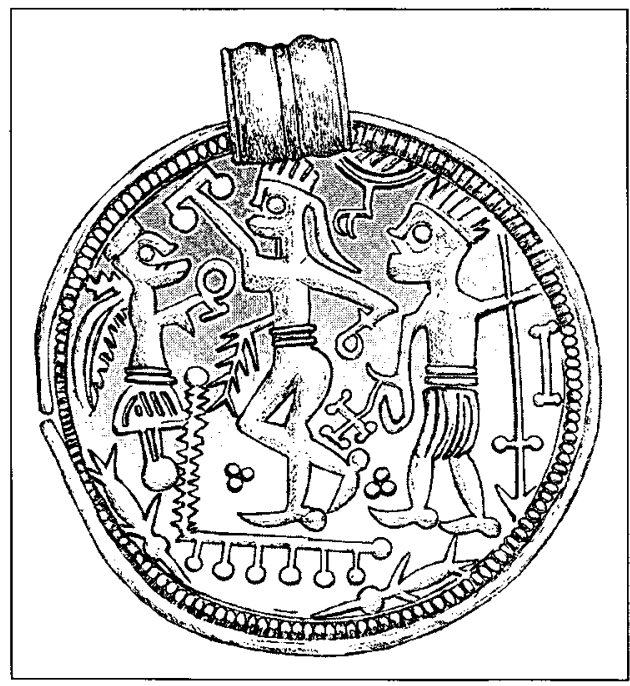

Fig. 2. Bracteate from Fakse, Zealand (Hauck 1992). as a sign of goodwill. The wolf bit off his hand when he understood that he had been tricked. The characteristics associated with Tyr are courage and eagerness to fight, and he was furthermore regarded as the god who decided which side would win the battles (Bæksted 1990:123ff). A bracteate from Års, in Denmark (fig. 4), is suggested by Arrhenius to depict the god Tyr, since the spear carried by the figure might be interpreted as the rune $T$, also called Tyr (Arrhenius 1987:113). On some of the bracteates which represent the death of Balder, the figure that has been interpreted as Odin holds the same kind of spear. The spear on the bracteate from Års points towards the figure himself, and Inger-Lise Kolstrup (1991:199) has interpreted this as symbolizing Odin's self-sacrifice as described in Hávamál. Odin sacrificed himself in order to gain knowledge and obtain the runes.

The warlike characteristics of Balder are virtually unsubstantiated, and therefore these bracteates should not be considered as appealing primarily to men. On the contrary, the death of Balder and his return from $\mathrm{Hel}$ after Ragnarok has been interpreted as

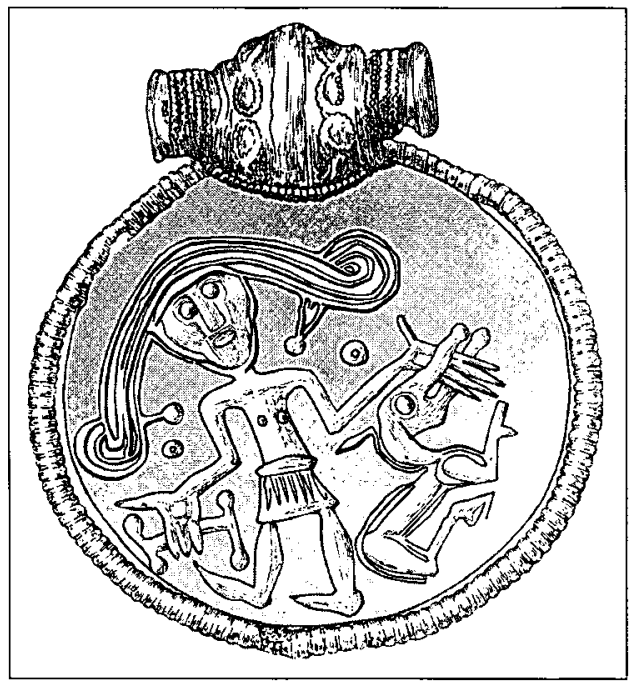

Fig. 3. Bracteate from Trollhättan, Västergötland (Hauck et al. 1985) 
symbolizing the recurring seasons and the eternal cycles of nature, where spring follows winter and death is followed by rebirth (Dumézil 1973:61). Balder is therefore more associated with fertility and agriculture than with aggression and war. Tyr's warlike characteristics have been over-emphasized. He is principally the god of law. There is not a single passage in the literature where Tyr is described on the battlefield (ibid:43). Therefore it is unlikely that these myths were chosen for the bracteates as militaristic symbols. Besides, the iconography should not be interpreted solely on the basis of the personal characteristics of the different gods.

Although Tyr and possibly Balder are gods that have some belligerent aspects to their characters, this is not the most important factor in the study of the iconography. The myths that have been identified are not wholly belligerent. It is entirely possible that the depicted myths were selected for altogether different reasons. Both myths - the death of Balder, and Tyr and the wolf Fenrir - involve violence and death but not in warlike situations. If that had been the main aim of the iconography

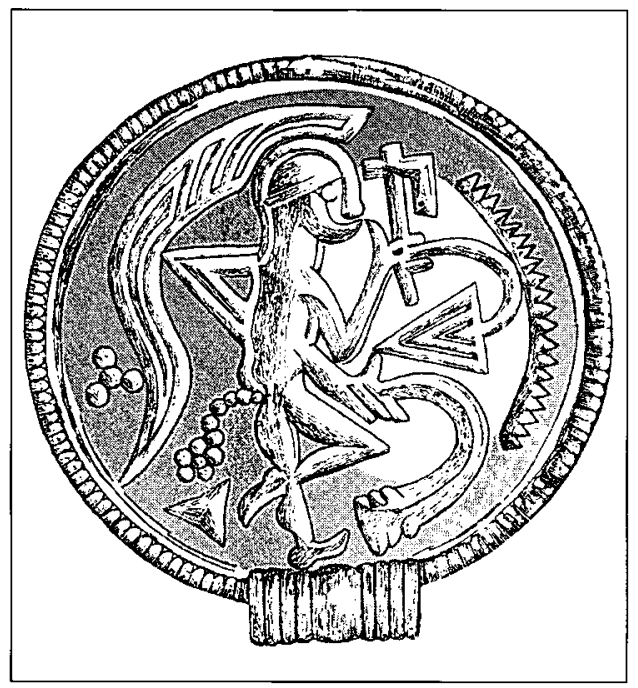

Fig. 4. Bracteate from Års, Jutland (Hauck et al 1985). it would not have been difficult to find more suitable examples from Germanic mythology. The iconography of these two groups of bracteates can therefore not be regarded as militaristic, and as such they would not have appealed only to male warriors. Thus there is reason to assume that the iconography attracted men and women alike which is not contradicted by the implications of the contexts of the finds.

\section{THE GODDESS WHO WEAVES}

A group of bracteates that have been found in Germany and Denmark depict a woman. The image is viewed as a weaving goddess by Michael J. Enright (1990) and the symbols that surround the depicted woman are interpreted as swifts, spindles and other weaving paraphernalia (fig. 5). The image, which has its origins of inspiration in the portraits of the weaving Virgin Mary in Byzantine art, has been adapted to Germanic mythology in which weaving metaphors are numerous. Weaving has ambiguous symbolic meanings, like most things in Norse mythology. In one passage from Njáls saga, weav-

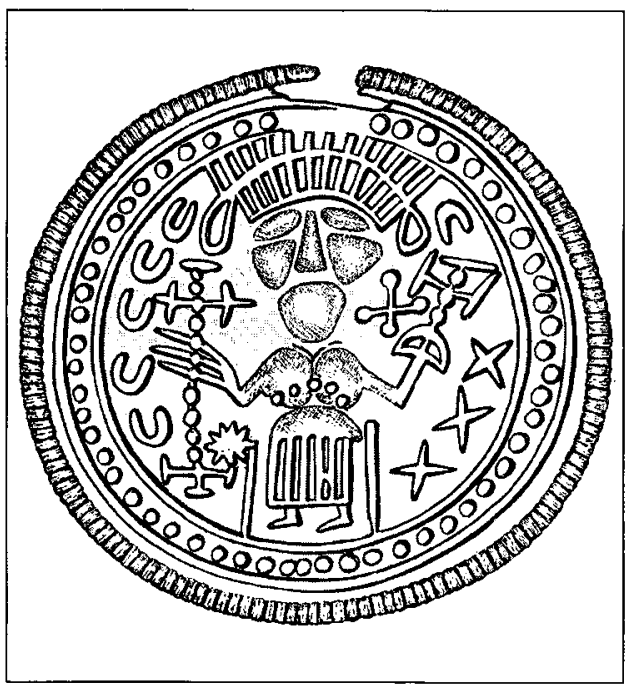

Fig. 5. Bracteate probably found in south-western Germany (Hauck et al. 1985) 
ing is related to valkyries and warfare. In Voluspá, however, weaving is associated with the Norns, and so indirectly with prophecy and fate. The non-militaristic symbolism is only mentioned cursorily in Enright's analysis. Instead the warlike characteristics of this weaving goddess are accentuated. It is also worth mentioning that this figure was, until quite recently, interpreted as a stylized man (ibid:58).

In Norse mythology weaving is also associated with the goddess Freyja, who is also known as Hörn. Hörn is closely related to the Old Icelandic word hörr and the Swedish dialectical word $h o ̈ r$, meaning linen. Traces of the cult of Hörn can be found in place-names, for example, in Härnevi which occurs in several cases in Uppland, in Sweden (Enright 1990:59). Another example where Hörn forms the origin of the name is Husaby- $\ddot{\mathrm{Ar}}$ nevi, which is the old name for the parish of Husby-Långhundra, Uppland (Calissendorff 1986:33). Hörn is primarily associated with female characteristics, which is indicated by the use of Hörn as a kenning for woman (Enright 1990:59). Another relevant aspect is that Hörn, or Freyja, is linked to the runic inscription linalaukaR on the Norwegian bone knives mentioned previously, which occur only in female graves.

\section{BRACTEATES AND POWER}

One conclusion which might be drawn from this is that the iconography of the bracteates should not be seen as having exclusively male associations, but rather, the symbolism might just as accurately be interpreted as female. Both men and women in the society of the
Migration Period would have been been able to relate to different elements within the imagery, and this is possibly reflected in southern and western Norway where bracteates have been found in both male and female contexts.

The bracteates can hardly be labelled male or female but can be considered to have androgynous symbolic meanings. Since there is reason to believe that we can only interpret fragments of this culturally-defined symbolism, it would be pointless to attempt to categorize gold bracteates as male or female based on such insubstantial evidence. This would only result in further deviation from the original, deliberate ambiguity of the symbolic language.

The bracteates found in female hoards and graves demonstrate the (albeit indirect) influence of women in political matters, and therefore women can not be regarded as passive onlookers who were only involved in exceptional circumstances.

The symbolic meaning of the bracteates is elusive and the message of the bracteates is not yet deciphered in its entirity. The same can be said of the find contexts where bracteates can not easily be classified since they are found in both hoards and graves, and in both male and female contexts. Whether bracteates are categorized as male or female is of minor significance; the people who wore gold bracteates held social status and the bracteates themselves represented power more than anything else.

\section{English revised by Laura Wrang.}

\section{REFERENCES}

Adolfsson, G. \& Lundström, I. 1993. Den starka kvinnan. Museiarkeologi 6. SHM Stockholm.

Andrén, A. 1991. Guld och makt - en tolkning av de skandinaviska guldbrakteaternas funktion.
Samfundsorganisation og Regional Variation. Red. Fabech, C. \& Ringtved, J. Jysk Arkæologisk Selskabs Skrifter XXVII. Århus. Pp. 245-256. 
- 1993. Doors to Other Worlds: Scandinavian Death Rituals in Gotlandic Perspectives. Journal of European Archaeology vol. 1. Pp. 33-56.

Arrhenius, B. 1987. Kring en ny brakteatcorpus. Fornvännen. Pp. 110-115.

- 1992. Smycken som diplomati. Föremål som vittnesbörd. En festskrift till Gertrud Grenander Nyberg på 80-årsdagen den 26 juli 1992. Nordiska museet. Pp. 18-25.

Arwill-Nordbladh, E. 1991. The Swedish Image of Viking Women. In: Social Approaches to Viking Studies. (Ed). Samson, R. Glasgow. Pp. 53-64.

- 1994. Begriper vi begreppen? Om androcentrismen $\mathrm{i}$ några vanliga analytiska begrepp. META. Lund,

Axboe, M. 1990. Odin og den romerske kejser. SKALK nr 4. Pp. 18-27.

- 1991. Guld og guder i folkevandringstiden. In: Samfundsorganisation og Regional Variation. (Eds). Fabech, C. \& Ringtved, J. Jysk Arkæologisk Selskabs Skrifter XXVII. Århus. Pp. 187-202.

- 1992. Guldbrakteaten från Nord-Edsten. Bohusläns årsbok 1992. Pp. 48-52.

Bagge, S. 1990. Mann og kvinne i Heimskringla. Fokus på kvinner $i$ middelalderkilder. (Eds). Jansen Sellevold, B., Mundal, E. \& Steinsland, G.

Breisch, A. 1994. Frid och fredlöshet. Studia historica Upsaliensia 174. Uppsala.

Brendalsmo, A. J. \& Røthe, G. 1992. Haugbrot eller de levendes forhold til de døde. META. Lund. Pp. 84-119.

Breksted, A. 1990. Nordiska gudar och hjältar. Oslo.

Calissendorff, K. 1986. Ortnamn i Uppland. Stockholm.

Dumézil, G. 1973. Gods of the Ancient Northmen. University of California Press.

Enright, M. J. 1990. The Goddess Who Weaves. Frïhmittelalterliche Studien. Band 24. Pp. 5470.

Fabech, C. 1991. Samfundsorganisation, religiøse ceremonier og regional variation. In: Samfundsorganisation og Regional Variation. (Eds). Fabech, C. \& Ringtved, J. Jysk Arkæologisk Selskabs Skrifter XXVII. Århus. Pp. 283-303.

Gurevich, A. J. 1985. Categories of Medieval Culture. London.

Guttormsson. L. 1992. Familjen. Den nordiske verden 2. Ed. Hastrup, K. Köpenhamn.

Hald, K. 1968. Personnamn. Kulturhistoriskt lexikon för nordisk medeltid. Band 13. Malmö. Pp. 217-226.

Hauck, K. (Ed). 1992. Der Historische Horizont der Götterbild-Amulette aus der Ühergangsepoche von der Spätantike zum Frïhmittelalter. Abhandlungen der akademie der wissenschaften in Göttingen. Philologisch-historische klasse dritte folge nr 200. Göttingen.

Hauck, K., Axboe, M., Düwel, K. \& von Padberg, L. 1985. Die Goldbrakteaten der Völkerwanderungszeit. Münstersche Mittelalterschriften 24/ 1-3. München.

Hedeager, L. 1992. Danmarks jernalder. Mellem stamme og stat. Århus universitetsforlag.

Hjørungdal, T. 1991. Det skjulte kjønn. Acta Archaeologica Lundensia. Lund.

Holtsmark, A. 1964. Kvinnearbeid. Kulturhistoriskt lexikon för nordisk medeltid. Band 9. Malmö. Pp. 565-574.

Jacobsen, L. 1935. Forbandelseformularer i nordiske runeinskrifter. KVHAA handlingar, del 39:4. Stockholm.

Jesch, J. 1991. Women in the Viking Age. The Boydell Press.

Jochens, J. 1986. The Medieval Icelandic Heroine: Fact or Fiction? Viator 17. Pp. 35-50.

Klintberg, L. 1996. Att hugga i sten. Om kvinnor som rumristare. Magisteruppsats. Arkeologiska institutionen. Stockholms universitet.

Kolstrup, I-L. 1991. Ikonografi og religion. Nordisk Hedendom. (Eds). Steinsland, G., Drobin, U., Pentikäinen, J. \& Meulengracht Sørensen, P. Odense universitetsforlag.

Lamm, J. P. 1994. Brakteater. Guldets magi i saga och verklighet. (Ed). Knape, A. SHM. Stockholm. Pp. 52-55.

Mackeprang, M. B. 1952. De nordiske guldbrakteater: Jysk Arkæologisk Selskabs Skrifter bd. II. Århus.

Magnus, B. 1992. A matter of literacy or magic? Peregrinatio Gothica III. Universitetets Oldsakssamlings Skrifter. Ny rekke nr 14. Oslo. Pp. 133-143.

Malmer, M. P. 1963. Metodproblem inom järnälderns konsthistoria. Acta Archaeologica Lundensia. Lund.

Meulengracht Sørensen, P. 1993. Fortelling og are - studier $i$ islondingesagaerne. Aarhus universitetsforlag. Århus.

Mundal. E. 1992. Norrøn litteratur som kjelde til 
nordisk kvinnehistorie. Kvinnospår i medeltiden. (Ed). Lövkrona, I. Kvinnovetenskapliga studier 1. Lund University Press. Pp. 93-113.

Näsman, U. 1988. Den folkvandringstida? krisen i Sydskandinavien, inklusive Öland och Gotland. In: Folkevandringstiden $i$ Norden. En krisetid mellem aldre og yngre jernalder. (Eds). Näsman, U. \& Lund, J. Århus.

Otterbjörk, R. 1968. Personnamn. Kulturhistoriskt lexikon för nordisk medeltid. Band 13. Malmö. Pp. 206-217.

Sawyer, B. 1992. Kvinnor och familj i det forn-och medeltida Skandinavien. Occasional Papers on Medieval Topics 6. Skara.

- 1994. Kvinnoporträtt. Hustrur, helgon och härskarinnor i det medeltida Sverige. Småskrift nr 4. Skaraborgs länsmuseum. Skara.

Steinsland, G. 1990. Antropologiske og eskatolo- giske ideer i førkristen nordisk religion. Collegium Medievale 1990/1. Pp. 59-72.

Steinsland, G. \& Vogt, K. 1981. "Aukinn ertu Uolse ok vpp vm tekinn". En religionshistorisk analyse av Volsapáttr i Flateyjarbók. Arkiv för nordisk filologi. Band 96. Pp. 87-106.

Strömbäck, D. 1935. Sejd. Textstudier i nordisk religionshistoria. Nordiska texter och undersökningar nr 5. Uppsala.

- 1968. Sejd. Kulturhistoriskt lexikon för nordisk medeltid. Band 15. Malmö. Pp. 76-79.

Vestergaard, E. 1991. Gift-Giving, Hoarding and Outdoings. In: Social Approaches to Viking Studies. (Ed). Samson, R. Glasgow. Pp. 97104.

Öberg, H. 1942. Guldbrakteaterna från Nordens folkvandringstid. KVHAA. Stockholm. 